\title{
7
}

\section{The Use of a Bookclub to Enhance Science Literacy and Understanding of Infectious Disease Epidemiology}

\author{
Joanna Verran
}

\section{The Birth of the Bad Bugs Bookclub}

This chapter describes the activities of a bookclub that brought scientists and non-scientists together to read novels where infectious disease formed part of the plot, and to consider how these novels could be used to promote a better understanding of disease and epidemiology (Treffry-Goatley 2017), and the work of the professional scientist. Fictions, and popular fictions in particular, have been used to support the understanding of complex concepts. Jarvis and Gouthro (2015) identify 'using arts to illustrate complex concepts and dilemmas' as one of five key ways in which academics use the arts in education. This can include scientific concepts and dilemmas, such as those explored by White (2008). Fewer investigations consider how this

\footnotetext{
J. Verran $(\bowtie)$

Manchester Metropolitan University, Manchester, UK e-mail: J.Verran@mmu.ac.uk 
might operate with the wider public — which is where the Bad Bugs Bookclub concept originated. A particular focus of the bookclub was to suggest how teachers in Higher Education might use these novels in their practice, but I believe that this specialised format, with a relatively narrow focus on subject matter but no limitation on genre, can be used to benefit a wide range of professional (and non-professional) audiences. With a focus on infectious disease, the Bad Bugs Bookclub has also been particularly targeted towards students reading for a degree in Biomedical Science. This degree is accredited by the Institute of Biomedical Sciences: graduates are professionally qualified to be employed as medical laboratory scientists. (The nature of student participation in bookclub meetings and related activities varies, and will be described later in the chapter.) The discussions that take place during bookclub meetings enable scientists to better understand how non-scientists perceive different aspects of science. The literature on fiction and education has identified its capacity for enabling learners to experience the feelings and perceptions of those from many different walks of life. Keen's work on empathy (2007) outlines the challenges associated with this, and many educators have used fiction to support a better understanding of the perceptions of those they feel are different or other (Tisdell and Thompson 2007). In the bookclub milieu, gaps in knowledge, misunderstandings and concerns can be addressed through conversation and explanation, without the need for the experts to resort to 'lecturing'. Fiction forms an important part of social discourse generally. Many people's perceptions of the professions is shaped, at least partially by popular fictions. Scientists abound in film and television, but their representation can be partial (Jubas 2015). The novels considered by the bookclub have enabled us to explore more fully aspects such as how the scientist is represented in literature; the role of female scientists in plot development; and the laboratory environment in which scientists operate-in terms of project development and delivery, teamwork, equipment and procedures. Indeed, in whatever form the bookclub has been delivered, and to whichever 'audience', it is apparent from discussions-meeting notes are recorded and logged on the website (Verran 2009) — that much is 
learnt about transmission of infection and treatment and emergence of disease, as well as about fiction and communication through conversation and creative writing.

As a microbiology lecturer, a key premise to my teaching philosophy was that students should be able to communicate their science knowledge and enthusiasm to different audiences. This would in turn demand understanding of scientific principles on their part, as well as different styles and modes of communication. As critical education theorists have pointed out, fostering effective communication is integral to supporting deeper forms of learning (Brookfield 2015; Mezirow 2000). Thus I developed a number of learning activities to enable the acquisition of communication skills. In particular, I encouraged the use of art as a medium for science communication. In a lecture to first-year microbiology undergraduates, using many examples, I asked what relationship microbiology has to art, and how art can be used to convey information about microbiology to audiences that may be less open to, or less familiar with, science (Verran 2010a). An associated assignment was the production of a creative output that illustrated some aspect of the topic.

As my students developed their outputs (for example using artwork, photography, music, fashion, 3D design, textiles), I began to consider the microbiology present in various works of fiction-indeed, one group of students was inspired by Louisa M. Alcott's Little Women (1869) to make a quilt embroidered with references to scarlet fever (Figs. 7.1 and 7.2).

As with art, fiction provides a medium that enables interactions between individuals with different knowledge and experience of science. Rather than a platform for knowledge transfer from scientist to audience (Fogg-Rivers and Hickman 2014), a bookclub meeting enables engagement and two-way-or rather multi-way_dialogue between 'expert' and 'non-expert'. Thus I launched the 'Bad Bugs Bookclub' in 2009 (Verran 2009, 2013a). Each member of the bookclub brings their own knowledge and experience to the meeting, enabling discussion on a level platform where all inputs are valued. 


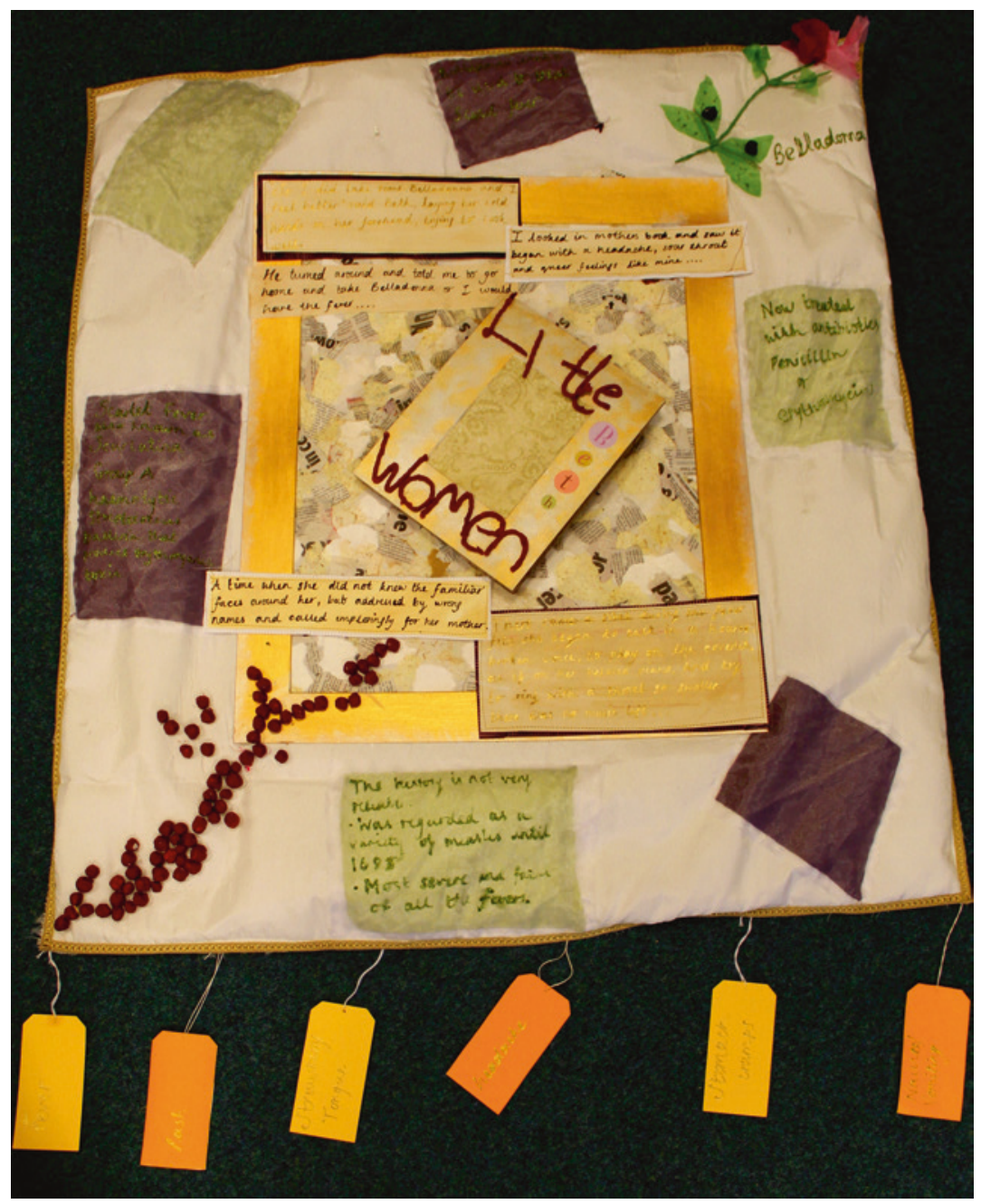

Fig. 7.1 A quilt inspired by the microbiology described in the novel Little Women produced by undergraduate biomedical science students Fahima Zahoor, Halima Rana, Sameena Khan, and Alia Khan (2011) 


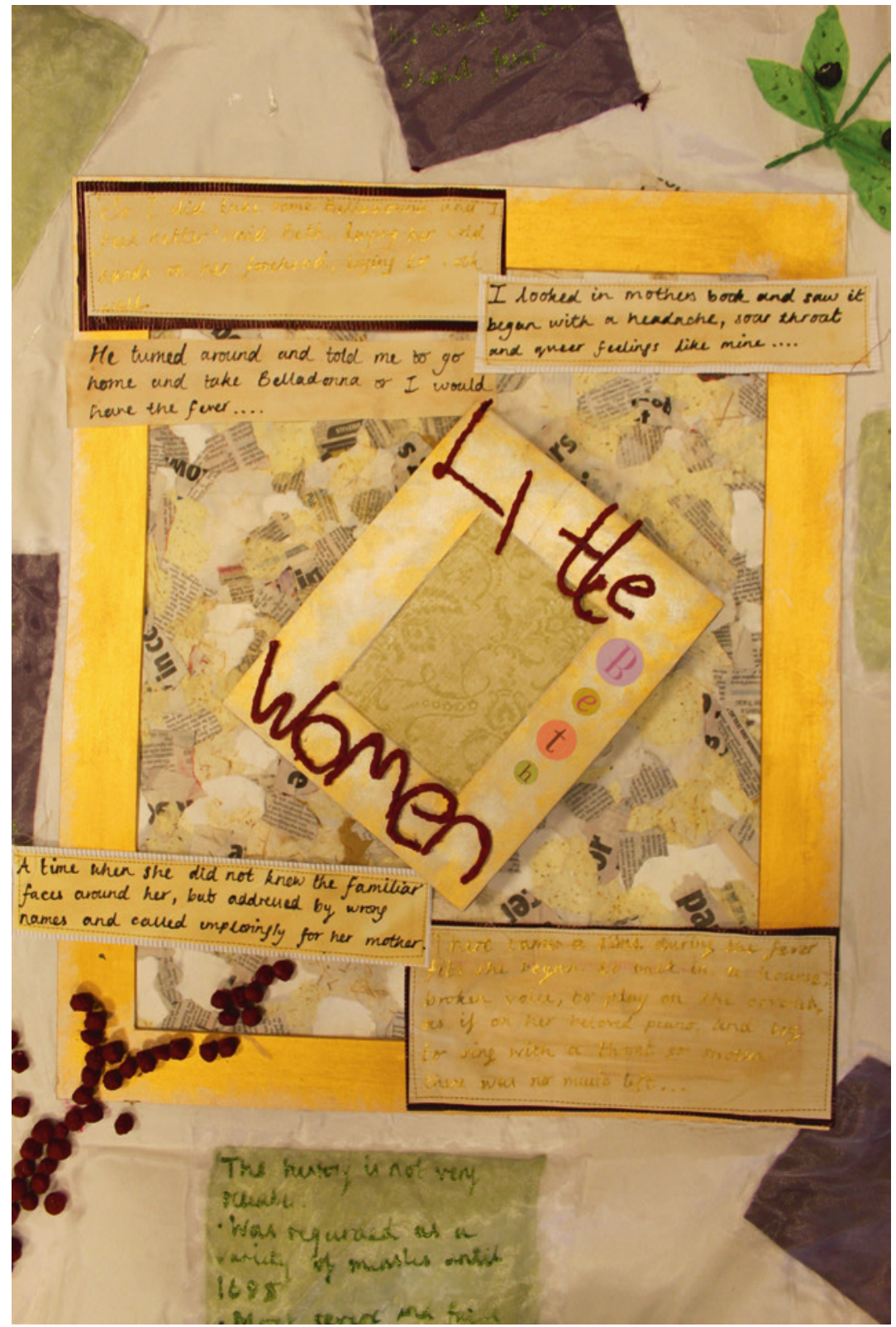

Fig. 7.2 Close up of quilt detail 


\section{Meeting Format}

Bookclubs, or reading groups, have increased in popularity since the late 1990s. Estimates in 2003 reckoned on around 50,000 in Britain and 500,000 in America (Hartley and Turvey 2002), with the majority meeting in person, in groups of 8-10 (BookBrowse, Morgan-Witts and Morgan-Witts 1997). The emergence of the 'active reader' stimulated a concomitant increase in media-, publisher- or celebrity-led bookclubs (Wilson 2017), enabling a rich resource of reading lists and reading guides. There are also specialised groups who read restricted genres such as crime fiction, science fiction or the classics.

The specialised focus of the Bad Bugs Bookclub was microbiologyparticularly infectious disease. The first meeting took place during a conference of an academic society: The Hot Zone by Richard Preston (1994) was discussed after the group had also watched the movie Outbreak (Petersen 1995), screened as part of National Science Week. These two events_-Science Week and a conference-enabled promotion of the first meeting of the bookclub through various email lists and websites. Around sixty attended the film screening, and eight came to the bookclub meeting, a self-selected group comprising scientists (microbiologists-representatives from academia, postgraduates and undergraduates) and non-scientists - typically members of the public with an interest in science. A meeting report and a reading guide were produced and posted on a dedicated website (Verran 2009), thus beginning the development of a significant resource.

Nine years and more than fifty books later (Table 7.1), the resource remains available with reading guides free to download alongside reports of every meeting held. Approximately six meetings are held each year, often combined with film screenings, walks or other events. Meetings may be held on special days in the microbiology calendar, for example World AIDS Day (December 1). Therefore, at any meeting, the date for the next meeting is agreed, along with the book title. Email reminders are sent to group members, but an open invitation is made via the website. A typical meeting takes place in a local pub, comprising around eight individuals, of which half have been members since the beginning of the group. There is no gender bias in membership, unlike 
๑ बे

ڤ है

히음

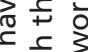

ํำ

응ㅎㅇ

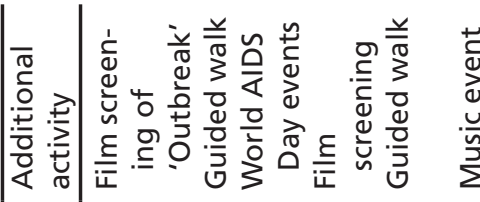

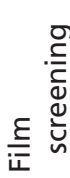

品

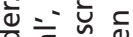

흥 은 웡

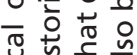

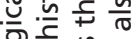

응 웡

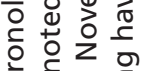

는

$\leq 0$ 过

$\infty \pi$ \&

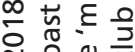

Tे

웡 㝎 흥

유.출을

น

ดั ญ

>े

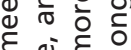

$\varepsilon$ बं $\varepsilon$ 응

윽 을 눙

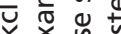

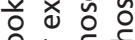

它它

㟔

口ㅇํํ

○

Ф

의 단

츨 음

วิㅇㅇㅊ

ट $\frac{2}{\overline{0}}$

बूँ घ

ช。

ํㅡㄴ 율

웡 응

든

ठำ 는

$z$ o

-

ヘิ

๗ั๐ รั

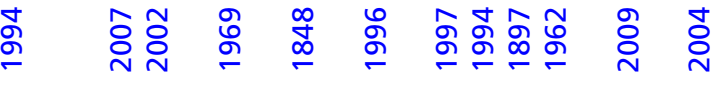

这

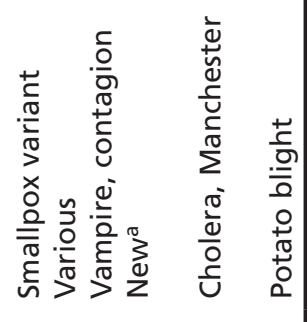

인 $\frac{\pi}{2}$

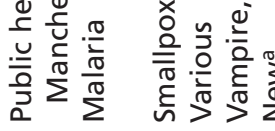

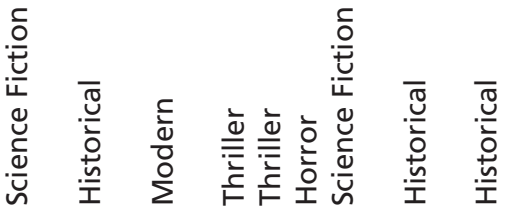

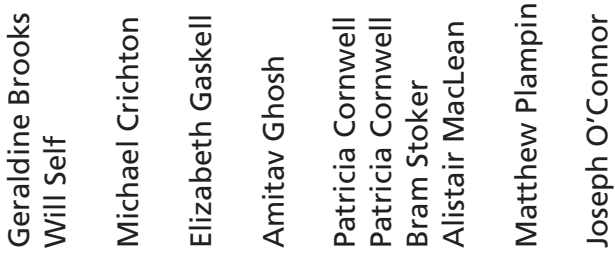

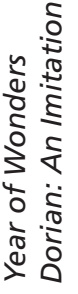

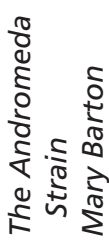

కั้

กั ई

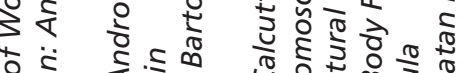
U.

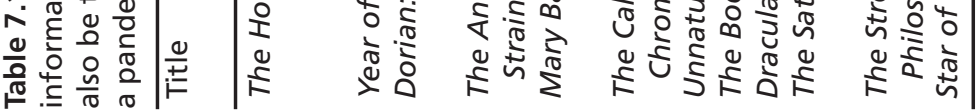




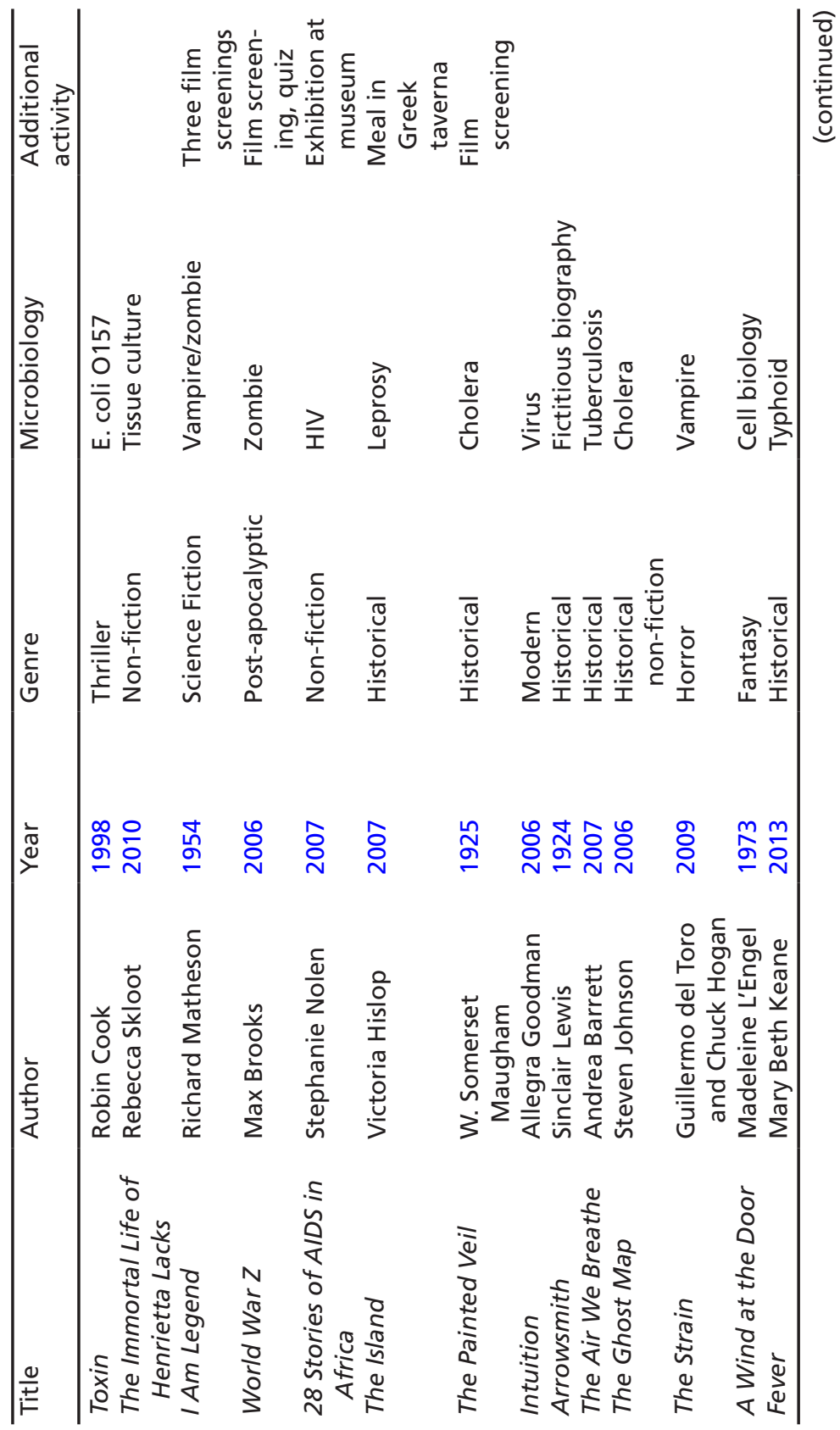




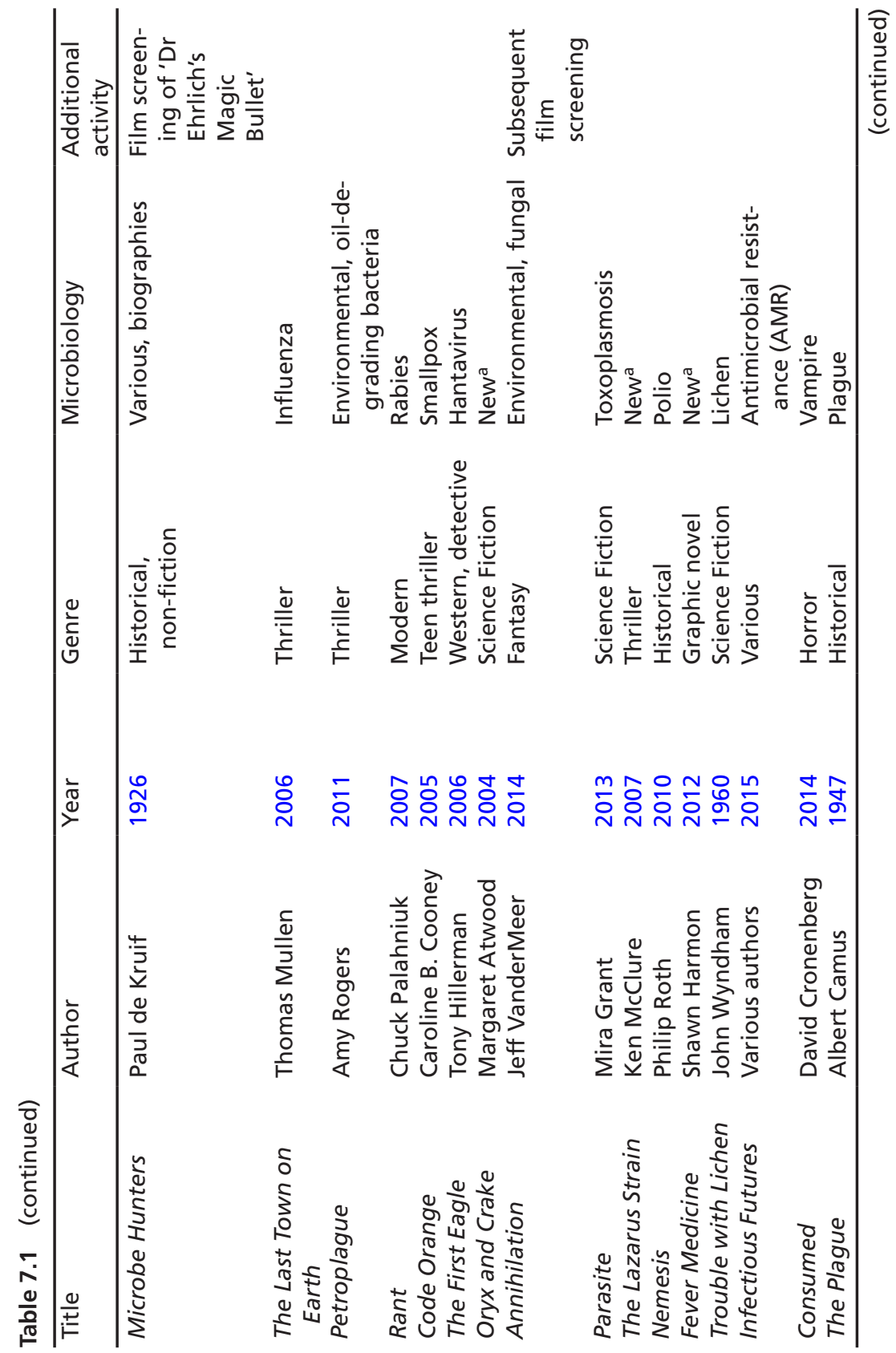




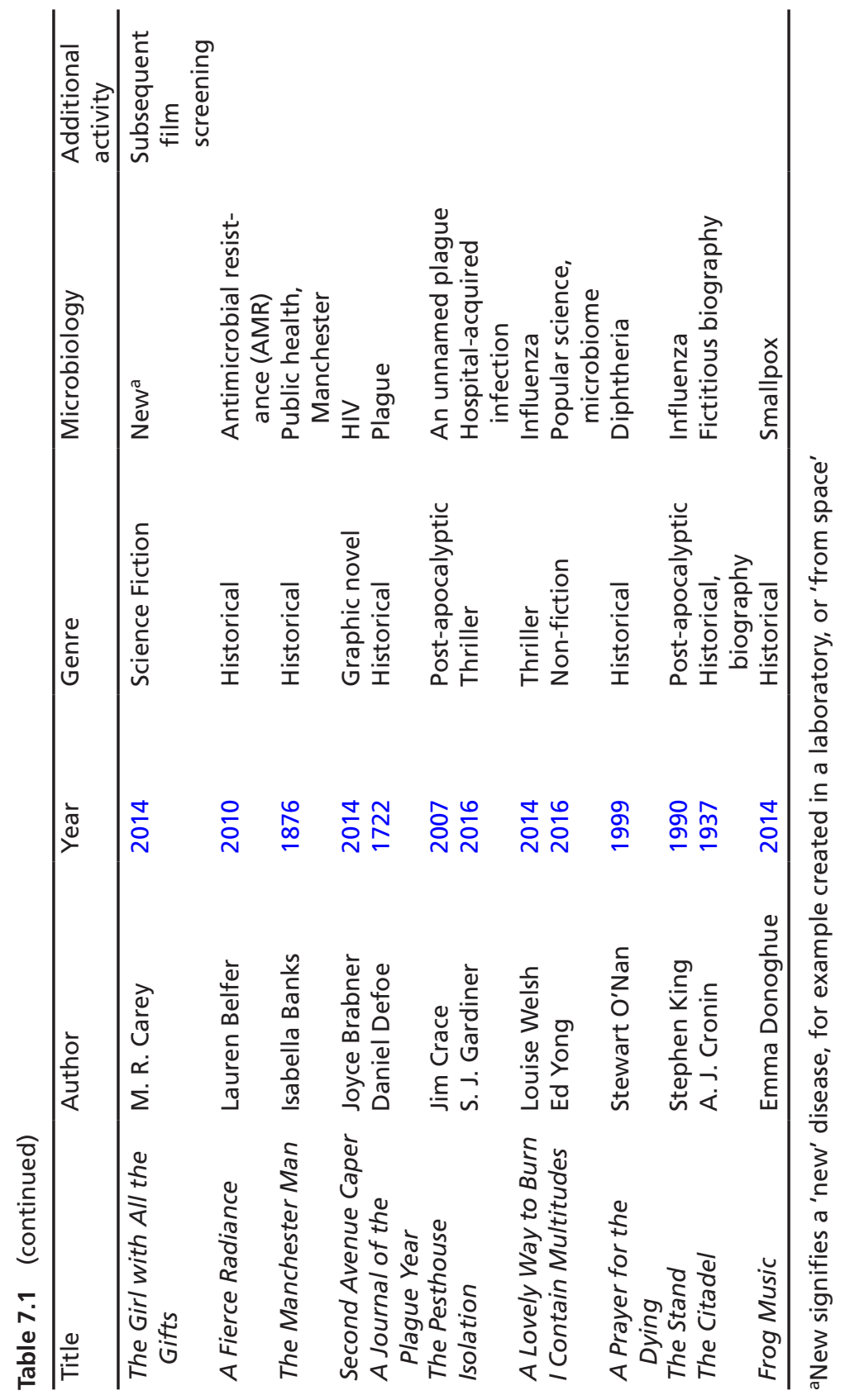


the majority of bookclubs whose members are predominantly women (Long 2003). Student membership of this open bookclub has remained voluntary (and small), but opportunities have arisen for them to help in devising and delivering accompanying activities (for example through the STEM Ambassadors' Scheme or University employability initiatives), or to host their own events as part of final year dissertation work.

Questions are prepared by the meeting host (the member who has selected the book) or the bookclub leader (the author of this chapter), who also leads the discussion. These questions initially focus on the members' impressions of the novel-its writing style, characters and plot. Other trigger questions explore the microbiology and epidemiology of the infection itself, or infections that bear some resemblance to a particular disease. This latter aspect is appropriate for novels that explore apocalyptic tropes, such as zombie pandemics, or a newly engineered highly virulent strain of influenza. Specific aspects related to the novel, such as the representation of the science, scientist, women, ethics, current concerns and emerging diseases, are also addressed, enabling reflection and consideration of the relationship between fact and fiction in literature, and in the 'outside world' (Verran and Aldana Reyes 2018).

Finally, and importantly for the focus of this chapter, we consider whether, and how, the novel could be used in an overt education setting, primarily for biomedical science undergraduates (and, where appropriate, for students in other disciplines and levels). For some books, reading guides were not provided on the basis that there was too much science content (I Contain Multitudes, Yong 2016), a lack of science content (The Strain, del Toro and Hogan 2009; Consumed, Cronenberg 2014), or being inappropriate for general reading by biomedical science undergraduates (Rant, Palahniuk 2007; Dorian: An Imitation, Self 2002).

\section{The Bad Bugs Bookclub in Professional Education-Case Studies}

The bookclub format and the microbial science angle has been modified and developed for many different audiences: 


\section{Children/Families/Teachers}

The annual Manchester Children's Book Festival (MCBF) was launched in 2010, the aim being to 'create an explosion of activity celebrating children's books in the city of Manchester' (MCBF 2010). The Family Fun Day comprises a range of events including author readings, storytelling, exhibitions and other activities. The Bad Bugs Bookclub provided a 'science corner', focusing on microbiological aspects of the (then) popular teen novel Twilight (2005) by Stephenie Meyer (Verran 2010a). For example, Edward, the hero, became a vampire in 1918 to prevent his death from influenza, thus the transmission and prevention of influenza was compared to that of vampirism and other diseases transmitted by biting. Extending this work to include zombies, a second workshop utilised a game, SimZombie (Verran et al. 2013), to demonstrate the spread of the zombie condition as illustrated in four children's novels: Boneshaker (Priest 2009), Warm Bodies (Marion 2011), Rot and Ruin (Maberry 2010) and The Enemy (Higson 2009). A third workshop in 2014 compared the emergence of smallpox with that of zombie-ism using Code Orange (Cooney 2005) and a newly developed game, SimFection (Carolan et al. 2018). In all of these activities, students helped to plan and deliver events, some as volunteers and others as part of their final year dissertation.

To support student teachers, workshops were hosted showing how the games and books could be used to educate about infectious disease in line with the curriculum. In effect, lesson plans were developed (in this case by a Ph.D. student working with an undergraduate) highlighting segments of the novels that addressed disease transmission and prevention, and encouraged the audience to define epidemiological parameters for the infection described in a particular novel. These parameters were input into SimZombie or SimFection; the resultant simulations revealed the impact of varying contributory factors on the spread of infection.

In 2016, the MCBF selected book was Compton Valance: the Most Powerful Boy in the Universe by Matt Brown (2014). Compton keeps a cheese and pickled egg sandwich in a shoebox under his 
bed for 13 weeks, after which he eats parts of it and discovers that it has given him time-travelling powers. The microbiological element of this is clearly the 13-week incubation of the sandwich, thus we carried out an experiment to see what would actually happen under these conditions (https://www.youtube.com/watch?v=k1B4wFf_8Z8 for the story; and a time-lapse film at https:/www.youtube.com/ watch?v=NY9leVeLZo8). We brought the 13-week old soil-like remnants of the sandwich (sealed in a transparent sandwich box) to the Family Fun Day, along with microscopes and fungal cultures, and talked about food hygiene and safe sandwich production, storage and consumption (Fig. 7.3). The author Matt Brown noted: "It was a personal thrill to have a team of real scientists work through the science of my Compton Valance books... I loved what she did and really think that it will have sent kids home, fizzing with inspiration. I was also very pleased to note that my description of a thirteen-anda-half week old cheese and pickled egg sandwich was pretty accurate.

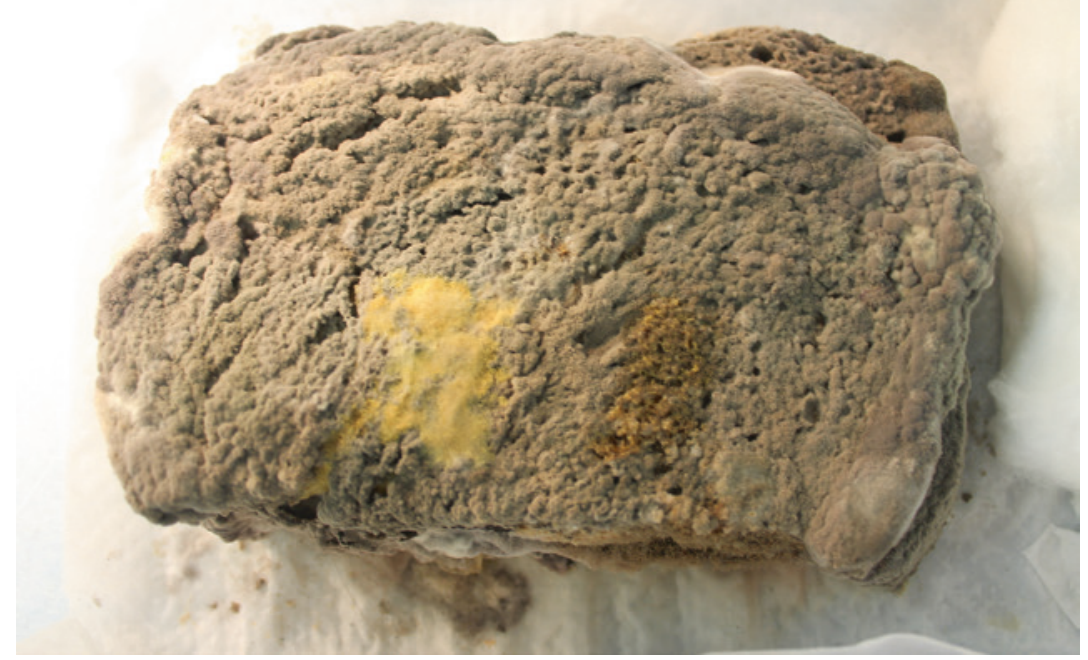

Fig. 7.3 A 13-week old cheese and pickled egg sandwich in reality 
It really did smell worse than having twenty rhinoceroses farting right in your face".

\section{Microbiologists}

There are several examples where non-fiction, rather than fiction, has been used by academics to explore the nature of science with undergraduate students (Aune et al. 2018; Griffard et al. 2013). From its inception, it had been decided that non-fiction would not be a focus for the Bad Bugs Bookclub. We would focus on more accessible works of fiction that enable wide-ranging discussion around accuracy, misunderstanding, and transferability to the 'real world', whilst developing science literacy 'through the back door'. Nevertheless, some works of non-fiction have crept into the canon: The Immortal Life of Henrietta Lacks (Skloot 2010), Microbe Hunters (de Kruif 1926), 28 Stories of AIDS in Africa (Nolen 2007), The Ghost Map (Johnson 2006), and I Contain Multitudes (Yong 2016). Of these, all but I Contain Multitudes are written as stories, and thus retain more informal entertainment value better suited to our reading group. There has recently been a significant surge in non-fiction books focusing on microbiology, perhaps reflecting interest in the human microbiome, antimicrobial resistance and the importance of infectious disease to global health, such as Mark Pallen's (2018) fascinating account of the Birmingham smallpox outbreak The Vaccine Race (Wadman 2017) and How to Survive a Plague (France 2017).

Several meetings of the Bad Bugs Bookclub have been held at national and international microbiology conferences, where participants are primarily university academics. The events were intended to encourage other faculty to use fiction as a resource for teaching and learning in their own educational contexts. Novels were selected to complement the conference theme (for example, at an international conference in the United States, Star of the Sea [O'Connor 2004] focused on the Irish potato famine and immigration; and Toxin [Cook 1998], at a conference whose focus was food microbiology). These highly informal bookclub meetings can be particularly fruitful in 
highlighting recent developments in relevant aspects of microbial science, for encouraging spin-off bookclubs and for identifying/additional activities for students.

\section{Biomedical Science Undergraduates}

Following from the success of the bookclub outside the University, bookclub meetings were held for undergraduate Biomedical Science students as part of their second year studies, within the medical microbiology module, replacing one tutorial (of five taken across the module by each student): attendance was required, but there was no other associated assessment. Four novels were selected, and one was assigned to each tutorial group (150 students divided into eight tutorial groups, with two groups reading the same book). The four novels were:

- I Am Legend (1954) by Richard Matheson (a short novel, addressing aspects of the cause of disease within a zombie/vampire apocalypse);

- Nemesis (2010) by Philip Roth (a short novel, easy to read, addressing polio epidemiology in the 1950s);

- The Immortal Life of Henrietta Lacks (2010) by Rebecca Skloot (an award-winning narrative describing the origin, history and value of HeLa cells to science and associated ethical issues);

- Microbe Hunters (1926) by Paul de Kruif (comprising Reader's Digest-style mini-biographies about pioneer microbiologists).

All tutorials were led by one academic (JV), using the appropriate reading guide posted on the Bad Bugs Bookclub website. Thus the aims of the bookclub sessions were the same as those for the 'usual' bookclub. It has been noted (Dixon 2002) that description of disease experience in fiction is more emotive - and can therefore be more memorable - than in the 'sober prose of the typical textbook': perhaps the more colourful text and the reader's investment in fictitious but human characters enable impact to be better embedded. In all cases, some (never all) students had read the book: students who had not read the book still contributed to discussion-particularly for I Am Legend, where they all 
had experience of games, films or books about zombies and/or vampires which could be extrapolated to discussion on transmission of the condition. For Nemesis, students' experience of vaccination against polio (and other diseases) was explored. Evaluation of the activity was informal and observational. Follow up activities as to the impact of this learning experience on subsequent reading were not carried out.

Improvements that were identified and suggested for future course delivery included the following: more tutors and smaller student groups to focus discussion and enhance engagement; the bookclub tutorial timetabled well before any assignment submission date and sufficiently well into the term to give students time to read the novels; book selection refined to enable a comparable reading experience; and some element of summative assessment to encourage participation by more students (Aaronson 2008). More emphasis on the value of 'science literacy' might also be beneficial prior to commencing the tutorial series (Calman et al. 1988): a narrative theory of learning draws attention to the various forms of critical literacies that can benefit students in professional studies. In addition, students could also be stimulated to produce their own creative writing outputs, for example by writing case studies - of great value on biomedical science and medicine education-using more personal stories (Yuan and Benson 1995): even comics have been used in medical education and patient care (Green and Myers 2010). These modifications have not yet been implemented due to course development and staffing limitations.

In many cases, some scientific aspects of the novel can be validated by perusal of the scientific literature. Thus an additional useful activity (again, not tested) would be for students to supplement the reading of fiction with an examination of peer-reviewed outputs, in order to synthesise a critical evaluation of the science as represented in the novel, and to see the lineages between narrative fictions and scientific scholarship. For example, fungal parasites that infect ants (Evans et al. 2011) are the cause of human infection in The Girl with All the Gifts (Carey 2014). Microbiology (Benbow et al. 2013) has great potential to play a part in forensic medicine, such as that described in the investigations of the deterioration of human cadavers in Patricia Cornwell's The Body Farm (1994). Neurological disease and 
behavioural change (Flegr 2013) has been associated with infection by Toxoplasma gondii described in Parasite (Grant 2013).

Final year undergraduate student projects can be laboratory-focused, a meta-analysis, or a public engagement activity. Thus students have devised, hosted and evaluated bookclub meetings as part of their project work (Verran 2013a, b) in the absence of a member of academic staff. A thorough reading of the novel being studied, preparation of questions and an understanding of key microbiology themes are essential preparation, as well as a serious approach to the event (since the reading group is often comprised of the student's friends or colleagues). One student selected AIDS Sutra: Untold Stories from India (Akhavi 2008) for discussion because it focused on her country of origin where AIDS was rarely mentioned. Another considered comparison of Semmelweis's work with content related to childbed fever and Streptococcus pyogenes in the novel The Bone Garden (Gerritsen 2007). A third used existing reading guides to assess their value for student reading groups. A fourth focused on her interest in the human microbiome to develop, deliver and evaluate a public event at Manchester Museum of Science and Industry to raise awareness of probiotics and fermented foods: she is a co-author on the resultant publication (Verran et al. 2018b). For all of these students, activities directly helped secure employment (teaching, medical communications), by evidencing valuable skills.

\section{Adults}

It is common for science advocates to blame fiction for negative public attitudes to science, or for the public's 'ignorance' about scientific facts (Orthia et al. 2011). It has also been noted that adults are one of three underserved audiences in terms of engagement with science (Lloyd et al. 2012). Addressing both of these issues, the bookclub format enables democratic engagement between (interested) adults in a relaxed setting, and the presence of 'experts' in the bookclub enables controversial issues or misunderstandings which arose during discussion to be explored in an informal manner. For example, Nemesis (Roth 2010) provides information about polio and its epidemiology that informed discussion 
around vaccination. World War $Z$ (Brooks 2006) enabled wide-ranging discussion about the behaviour of different populations when exposed to an apocalyptic scenario.

By combining bookclub meetings with additional events taking place for example during science festivals, opportunities arise to engage with new individuals and audiences, such as through guided walks (obviously facilitated by novels with local interest) or complementary (concomitant or subsequent) film screenings. For World Malaria Day (25th April 2010) the bookclub hosted a family-friendly musical event on a Sunday afternoon with performances by a poet and local musicians with an interest in world music. The author and musicians had met previously for a briefing meeting about malaria to enable preparation and development of the performances: the focus of the event was on immigration and travel. The venue displayed relevant student art, including information on their research and reflections that helped to create the outputs (Verran 2010b), and the event also included talks, games and fund-raising activities to entertain the audience of around fifty. The bookclub meeting (The Calcutta Chromosome, Ghosh 1996) was held in the evening attended by the usual small membership. However, some attempts to host bookclub meetings alongside or after family events were unsuccessful (see below). Thus free-standing bookclub meetings tend to be the norm.

Although the bookclub was intended to be a vehicle for encouraging public engagement with microbiology and was essentially academic-led (despite the shared table philosophy described above), an unanticipated outcome was the intellectual stimulation that the activity provided to the author. Themes began to emerge from the readings. One theme was the use of vampires and zombies as models for infectious disease epidemiology, which led to the production of a range of learning activities and materials (Carolan et al. 2018; Verran et al. 2013). These materials focused on the development of computer models to illustrate the spread of disease, thus avoiding the pitfalls associated with trivialisation of topics and associated lack of student engagement (Houghton et al. 2016). Another was how emerging diseases such as new strains of influenza became subjects for fiction. This triggered interdisciplinary research with the University's Institute for Gothic Studies, the designation of 
'emerging infectious literatures' (Verran and Aldana Reyes 2018), and the author's enrolment on a Masters in Creative Writing. Thus the Bad Bugs Bookclub truly played a part in my own professional education: as a scientist, I had not had the opportunity to study fiction for many decades. I discovered wonderfully written, stimulating books such as Oryx and Crake (Atwood 2004), Nemesis (Roth 2010), Frog Music (Donoghue 2014) and Rant (Palahniuk 2007), and became much more aware of a range of misconceptions and misunderstandings about infectious disease amongst non-scientists. Lifelong learning was brought home to me most forcibly.

The nature of the bookclub reading itself provides additional research material that I have found valuable. Not surprisingly, novels reflecting current concerns about microbiology tend to emerge after the event itself (where is the SARS, MERS or Zika virus novel?). However, there are opportunities to extrapolate observations from historical fiction to the present day or the future: for example by considering contemporary treatments for infection; or the impact of future vaccination on disease incidence; or similarities between epidemiologies of conditions of the past and present.

Novels about bioterrorism, and legal/illegal deliberate engineering of new pathogens are fairly plentiful. For example, I Am Pilgrim (Hayes 2013 ) is a recent example of an attempt to use smallpox as a biological weapon. The Passage (Cronin 2010) is a science fiction tome describing the engineering and escape of a vampire-like disease, and in The Stand (King 1990), a new strain of influenza escapes. Controversies about the engineering of avian influenza ('birdflu') (Morens et al. 2012) reflect general concern about the emergence of a new lethal disease.

Literature focusing on HIV-AIDS is considerable, with both fiction and non-fiction publications describing contemporary issues which altered as treatments were developed and became more accessible. Indeed, some publications provide historical narrative, such as 28 Stories of AIDS in Africa (Nolen 2007). Although AIDS in Africa remains a significant problem, access to treatment has now improved the health of those affected (http://www.unaids.org/en/resources/presscentre/pressreleaseandstatementarchive/2012/july/20120706prafricatreatment). How to Survive a Plague (France 2017) describes partnerships between 
AIDS activists, scientists, patients and doctors in the United States, which helped to develop the drugs that turned HIV from a mostly fatal infection to a manageable disease. Novels such as Dorian (Self 2002) and the Armistead Maupin Tales of the City series (1978-2014) describe the experiences of people living with AIDS: the bookclub has existed through a changing pattern of HIV-AIDS epidemiology, enabling reflection on the different pressures acting on those with HIV-AIDS, and those whose decisions affect their health and wellbeing.

Antimicrobial resistance is a matter of grave concern. Microorganisms are becoming resistant to many different types of antibiotics with concomitant problems in not only treatment of infection but also in prophylaxis in surgery and immunosuppression (Bowater 2017). Yet few novels use this phenomenon as a plot device, perhaps because the impact tends to be on individuals and their families rather than on populations where there is more opportunity to develop a bigger story (more people infected). A range of different outputs, perhaps quicker to produce than the novel, has been produced recently. The graphic novel Surgeon $X$ (Kenney and Watkiss 2016), published with accompanying learning materials and activities, attempts to engage audiences in discussionand behaviour change-about a future without antibiotics. Infectious Futures is a series of short stories commissioned by Nesta (2015) describing a future where antimicrobial resistance is commonplace and much of our way of life has been irrevocably altered. Plays broadcast on BBC Radio 4 have described different scenarios: one, Resistance (McDermid 2017), where a resistant bacterium causes an apocalyptic pandemic spread initially through ingestion; and another, The Truth About Hawaii (Emanuel 2018), broadcast on BBC Radio 4 in January/February 2018 focuses on one child battling against a serious infection. A Fierce Radiance (Belfer 2010) is set at the end of the Second World War and at the beginning of the antibiotic era. It describes initial attempts to mass produce new antibiotics and decisions as to who should be the first recipients of these drugs. Although the book ambitiously encompasses virtually all genres (romance, war, espionage, murder, thriller, historical), it provided a platform for useful bookclub discussion. Additional bookclub meetings were planned using this novel as supplementary activities for public engagement events focusing on antimicrobial resistance, the 
search for new antibiotics and a comparison with pre-antibiotic treatment. However, although the events themselves were successful, no members of the public signed up for the bookclub: afternoon meetings were not attractive, and after evening events participants preferred to go home (Redfern et al. 2018; Verran et al. 2018a).

\section{Exhausting the Reading Pipeline}

Who would have thought that so many novels of fiction addressed aspects of infectious disease epidemiology? Might we eventually 'run out' of books to read? There are groups of books which do not directly provide information about infectious disease, but which are rich sources of material for discussion.

Whether of real (The Immortal Life of Henrietta Lacks, Skloot 2010; Microbe Hunters, de Kruif 1926) or imagined individuals (The Citadel, Cronin 1937; Arrowsmith, Lewis 1924), biographical novels provide excellent opportunities to explore contemporaneous and current issues around ethics (Skloot), the pre-NHS era (Cronin), treatment of disease (Lewis), and the ingenuity of early microbiology researchers (de Kruif). Three of these four publications were written by scientists or medical practitioners (Skloot is a science writer), and the content often echoes, or is influenced by, their own experiences. More recent publications by scientist-writers (for example, Robin Cook, Ken McClure, Amy Rogers, S. J. Gardiner) have also provided science-based thrillers with a microbiology focus. Such outputs provide opportunity to consider the importance of accuracy over imagination, and to compare writing styles.

A plot device is any technique in a narrative that is used to move the plot forward. Since the focus for the novels studied by the Bad Bugs Bookclub was infectious disease, there were occasions where the disease was very much background to the story, typically providing the setting within which the plot develops. Frog Music (Donoghue 2014) is set within a nineteenth century San Francisco during a smallpox epidemic. Similarly, in A Lovely Way to Burn (Welsh 2014), the protagonist pursues a murderer during the emergence of a virulent influenza pandemic. The Pesthouse (Crace 2007) describes a journey across America (West to East) some years after an apocalyptic pandemic, but we never know what the disease 
actually was. For these novels, we considered how the disease affected the plot, and tended to discuss the writing and the story itself rather than the microbiology. Three novels that dealt more overtly with the city of Manchester-thus providing local interest for the bookclub-than with infectious disease, were all set before or during the Industrial Revolution: everyday infections encountered by the characters demonstrated how disease impacted on public health (Mary Barton, Gaskell 1848; The Manchester Man, Banks 1876; The Street Philosopher, Plampin 2009).

Finally, bookclub members bring suggestions for new reading material to each meeting, using internet search tools to identify examples focusing on different topics (for example HIV-AIDS), or genres (thrillers, science fiction). Stories describing historical events shaped by disease [such as The Last Hours, Walters 2017], describing the life of a community who had imposed self-isolation during the Black Death) where infection is caused by something other than a microorganisms (Blindness, Saramago 1995), or is peripheral to the plot (Pure, Miller 2011) continue to provide a rich source of material for discussion.

The role of the educator in supporting discussions that can evolve from fiction involves helping learners to engage in deeper forms of learning. As Jubas and colleagues have shown (Jubas et al. 2017), fictions can stimulate reflection on public issues such as health and healthcare. A narrative theory of learning draws upon literary, psychological and critical social theories to consider how educators can expose learners to different perspectives and circumstances to broaden their viewpoints and gain insights into various social issues. Books that explore pandemics or the ethical implications associated with the production of antimicrobial agents can delve into these real-life concerns through fictional stories. Using literature in a creative way, such as through the Bad Bugs Bookclub, fosters this kind of dynamic and critical engagement in learning.

\section{Concluding Comments}

In this chapter, I have described the use of a bookclub/reading group format for exploring aspects of infectious disease epidemiology with a range of different audiences. For more than a decade, the Bad Bugs 
Bookclub has studied books from a range of genres. The content of the novels enables discussion that can be used to update the appropriate disease epidemiology, and/or consider current concerns regarding global health. The nature of the discussions can also provide students with a broader perspective on public understanding of science and communication skills (oral and written). However, despite the versatility that the bookclub format provides, the audiences benefitting from these activities have been limited, primarily because I have not promoted the resource or practice as yet. The online resource, comprising meeting reports and reading guides is a significant resource, freely available to anyone wanting to set up their own bookclub. In addition to the unassessed, and voluntary participation of students in the bookclub, there is potential for developing the format into a more formal learning activity for (science) students, as well as for utilising other science-based topics rather than microbiology (for example environmental science, medicine, genetics). It is hoped that this chapter will raise awareness of the use of a bookclub to support professional education.

Acknowledgements I would like to thank the member of the bookclub and the students and other audiences who have participated so enthusiastically in meetings and associated events. I would also like to thank the Microbiology Society and the Society for Applied Microbiology for their support (some financial) over the years. Finally, thank you to Christine Jarvis and Patricia Gouthro for their expertise, encouragement and assistance in the creation of this paper.

\section{References}

Aaronson, L. (2008). The 'novel approach': Popular fiction as a teaching tool in undergraduate microbiology courses. Focus on Microbiology Education, 15, 2-3.

Akhavi, N. (Ed.). (2008). AIDS sutra: Untold stories from India. Gurugram: Random House India.

Alcott, L. (1869). Little women. London: Dean and Sons.

Atwood, M. (2004). Oryx and Crake. London: Virago. 
Aune, J. E., Evans, L. L., \& Boury, N. (2018). Using nonfiction narratives in an English course to teach the nature of science and its importance to communicating about science. Journal of Microbiology and Biology Education, 19(1), 1-8.

Banks, I. (1876). The Manchester man. London: Hurst and Blackett Publishers. Barrett, A. (2007). The air we breathe. London: Windmill.

Belfer, L. (2010). A fierce radiance. New York: HarperCollins.

Benbow, M. E., Lewis, A. J., Tomberlin, J. K., \& Pechal, J. L. (2013). Seasonal necrophagous insect community assembly during vertebrate carrion decomposition. Journal of Medical Entomology, 50(2), 440-450.

Bowater, L. (2017). The microbes fight back: Antibiotic resistance. London: Royal Society of Chemistry.

Brabner, J. (2014). Second avenue caper: When goodfellas, divas, and dealers plotted against the plague. New York: Hill \& Wang.

Brookfield, S. D. (2015). Teaching students to think critically about social media. New Directions for Teaching and Learning, 144, 47-56.

Brooks, G. (2007). Year of wonders. London: HarperCollins.

Brooks, M. (2006). World War Z: An oral history of the zombie war. London: Gerald Duckworth.

Brown, M. (2014). Compton Valance, the most powerful boy in the universe. London: Usborne Publishing.

Calman, K. C., Downie, R. S., Duthie, M., \& Sweeney, B. (1988). Literature and medicine: A short course for medical students. Medical Education, 22(4), 265-269.

Camus, A. (1947). The plague. London: Penguin Books.

Carey, M. R. (2014). The girl with all the gifts. London: Orbit.

Carolan, K., Verran, J., Amos, M., Crossley, M., Redfern, J., Whitton, N., et al. (2018). SimFection: A digital resource for vaccination education. Journal of Biological Education, 1-10. https://doi-org.libaccess.hud.ac.uk/10. 1080/00219266.2018.1469534.

Cook, R. (1998). Toxin. London: Pan Macmillan, UK.

Cooney, C. B. (2005). Code orange. New York: Delacorte Press.

Cornwell, P. (1994). The body farm. London: Sphere.

Cornwell, P. (1997). Unnatural exposure. London: Sphere.

Crace, J. (2007). The pesthouse. London: Picador.

Crichton, M. (1969). The Andromeda strain. London: Arrow.

Cronenberg, D. (2014). Consumed. London: Fourth Estate.

Cronin, A. J. (1937). The citadel. Sevenoaks, UK: NEL Books.

Cronin, A. J. (2010). The passage. London: Orion. 
Defoe, D. (1722). A journal of the plague year. London: Penguin. de Kruif, P. (1926). Microbe hunters. New York: Harvest.

del Toro, G., \& Hogan, C. (2009). The strain. London: HarperCollins.

Dixon, B. (2002). Fiction, fact and reality. American Society for Microbiology (ASM) News, 68(5), 206-207.

Donoghue, E. (2014). Frog music. London: Picador.

Emanuel, O. (2018, January/February). The truth about Hawaii [Radio series]. Broadcast on BBC Radio 4. https://www.bbc.co.uk/programmes/b09ntd0h. Evans, H. C., Elliot, S. L., \& Hughes, D. P. (2011). Ophiocordyceps unilateralis: A keystone species for unravelling ecosystem functioning and biodiversity of fungi in tropical forests. Communicative and Integrative Biology, 4(5), 598-602.

Flegr, J. (2013). Influence of latent Toxoplasma infection on human personality, physiology and morphology: Pros and cons of the Toxoplasma-human model in studying the manipulation hypothesis. Journal of Experimental Biology, 216(1), 127-133.

Fogg-Rivers, L. A., \& Hickman, M. (2014). The people, the people, the people: Engaging under-served audiences. In British Science Association (Ed.), Collected thoughts 2014: Essays inspired by the annual science communication conference (pp. 1-5). London: British Science Association.

France, D. (2017). How to survive a plague: The story of how activists and scientists tamed AIDS. London: Picador.

Gardiner, S. J. (2016). Isolation [eBook]. http://www.fahrenheit-press.com/ authors_sj_gardiner.html.

Gaskell, E. (1848). Mary Barton: A tale of Manchester life. London: Chapman and Hall.

Gerritsen, T. (2007). The bone garden. London: Transworld Publishers.

Ghosh, A. (1996). The Calcutta chromosome: A novel of fevers, delirium and discovery. London: Picador.

Goodman, A. (2006). Intuition. London: Atlantic.

Grant, M. (2013). Parasite. New York: Orbit.

Green, M. J., \& Myers, K. R. (2010). Graphic medicine: Use of comics in medical education and patient care. British Medical Journal (BMJ), 340(7746), 574-577.

Griffard, P. B., Mosleh, T., \& Kubba, S. (2013). Developing the inner scientist: Bookclub participation and the nature of science. CBE-Life Sciences Education, 12(1), 80-91.

Harmon, S. (2012). Fever medicine. Edinburgh: School of Law, University of Edinburgh. 
Hartley, J., \& Turvey, S. (2002). The reading groups book. Oxford: Oxford University Press.

Hayes, T. (2013). I am pilgrim. London: Transworld Publishers.

Higson, C. (2009). The enemy. London: Puffin.

Hillerman, T. (2006). The first eagle. New York: HarperCollins.

Hislop, V. (2007). The Island. London: Headline Publishing Group.

Houghton, F., del Monte, K., Glessner, D., Goff, J., Hopkins, E., Loney, K., et al. (2016). Zombie pandemic preparedness: A cautionary observation. New Zealand Medical Journal (NZMJ), 129(1432), 97-99.

Jarvis, C., \& Gouthro, P. (2015). The role of the arts in professional education: Surveying the field. Studies in the Education of Adults, 47, 64-80.

Johnson, S. (2006). The ghost map. London: Penguin.

Jubas, K. (2015). Giving substance to ghostly figures, how female nursing students respond to a cultural portrayal of 'women's work' in health care. In K. Jubas, N. Taber, \& T. Brown (Eds.), Popular culture as pedagogy (pp. 83-102). Rotterdam: Sense.

Jubas, K., Johnston, D., \& Chiang, A. (2017). Public pedagogy as border-crossing: How Canadian fans learn about health care from American TV. Journal of Borderlands Studies, published online August 28, 2017. https://doi.org/10.1080/08865655.2017.1367319.

Keane, M. B. (2013). Fever. London: Simon and Schuster.

Keen, S. (2007). Empathy and the novel. Oxford, UK: Oxford University Press. Kenney, S., \& Watkiss, J. (2016). Surgeon X [Comic book series]. Berkeley: Image Comics Inc.

King, S. (1990). The stand. London: Hodder and Stoughton.

L'Engel, M. (1973). A wind at the door. New York: Macmillan Square Fish.

Lewis, S. (1924). Arrowsmith. New York: Signet Classics.

Lloyd, R., Neilson, R., King, S., \& Dyball, M. (2012). Review of informal science learning. London: Wellcome Trust.

Long, E. (2003). Bookclubs: Women and the uses of reading in everyday life. Chicago: University of Chicago Press.

Maberry, J. (2010). Rot and ruin. London: Simon and Schuster.

MacLean, A. (1962). The satan bug. London: Collins.

Manchester Children's Book Festival. (2010). MCBF [Festival]. www.mcbf.org.uk.

Marion, I. (2011). Warm bodies. London: Vintage.

Matheson, R. (1954). I am legend. New York: Fawcett Publications.

Maupin, A. (1978-2014). Tales of the city. London: Black Swan.

McClure, K. (2007). The Lazarus strain. London: Allison and Busby. 
McDermid, V. (2017). Resistance [CD recording]. London: BBC Physical Audio.

Meyer, S. (2005). Twilight. New York: Little Brown.

Mezirow, J. (2000). Learning to think like an adult: Core concepts of transformation theory. In J. Mezirow \& Associates (Eds.), Learning as transformation: Critical perspectives on a theory in progress (pp. 3-33). San Francisco, CA: Jossey-Bass.

Miller, A. (2011). Pure. London: Sceptre.

Morens, D. M., Subbarao, K., \& Taubenberger, J. K. (2012). Engineering $\mathrm{H} 5 \mathrm{~N} 1$ avian influenza viruses to study human adaptation. Nature, 486(7403), 335-340.

Morgan-Witts, D., \& Morgan-Witts, P. (Founders). (1997). BookBrowse [Website]. https://www.bookbrowse.com/index.cfm.

Mullen, T. (2006). The last town on Earth. London: Harper Perennial.

Nesta (Formerly NESTA, National Endowment for Science, Technology and the Arts) (Commissioners). (2015). Infectious futures [Short story series]. https://www.nesta.org.uk/report/longitude-prize-infectious-futures/.

Nolen, S. (2007). 28 stories of AIDS in Africa. London: Portobello.

O'Connor, J. (2004). Star of the sea. London: Vintage.

O'Nan, S. (1999). A prayer for the dying. New York: Picador.

Orthia, L. A., Dobos, A. R., Guy, T., Kan, S. Z., Keys, S. E., Nekvapil, S., et al. (2011). How do people think about the science they encounter in fiction? Undergraduates investigate responses to science in the Simpsons. International Journal of Science Education, Part B: Communication and Public Engagement, 2(2), 149-174. https://doi.org/10.1080/21548455.2011. 610134.

Palahniuk, C. (2007). Rant: The oral history of Buster Casey. New York: Anchor. Pallen, M. (2018). The last days of smallpox: Tragedy in Birmingham. Independently Published.

Peterson, W. (Director). (1995). Outbreak [Motion picture]. USA: Warner Bros., Arnold Kopelson Productions, Punch Productions and Kopelson Entertainment.

Plampin, M. (2009). The street philosopher. London: Harper.

Preston, R. (1994). The hot zone. London: Doubleday.

Priest, C. (2009). Boneshaker: A novel of the clockwork century. New York: Tor Books.

Redfern, J., Bowater, L., Crossley, M., \& Verran, J. (2018). Spreading the message of antimicrobial resistance: Case studies exploring the development of a 
successful public engagement event. FEMS Microbiology Letters. https://doi. org/10.1093/femsle/fny175.

Rogers, A. (2011). Petroplague. New York: Diversion Books.

Roth, P. (2010). Nemesis. London: Vintage.

Saramago, J. (1995). Blindness. London: Vintage.

Self, W. (2002). Dorian: An imitation. London: Penguin.

Skloot, R. (2010). The immortal life of Henrietta Lacks. New York: Crown.

Somerset Maugham, W. (1925). The painted veil. London: Heinemann.

Stoker, B. (1897). Dracula. London: Archibald Constable and Company.

Tisdell, E. J., \& Thompson, P. M. (2007). 'Seeing from a different angle': The role of pop culture in teaching for diversity and critical media literacy in adult education. International Journal of Lifelong Education, 26(6), 651-673.

Treffry-Goatley, A. (2017). Narratives of illness in South African cinema: What can popular culture teach us about HIV? In K. Jubas, N. Taber, \& T. Brown (Eds.), Popular culture as pedagogy (pp. 103-118). Rotterdam: Sense.

VanderMeer, J. (2014). Annihilation. London: Fourth Estate.

Verran, J. (Creator). (2009). Bad Bugs Bookclub [Website]. https://www2. mmu.ac.uk/engage/what-we-do/bad-bugs-bookclub/.

Verran, J. (2010a). Encouraging creativity and employability skills in undergraduate microbiologists. Trends in Microbiology, 18(2), 56-58.

Verran, J. (2010b). Public engagement and innovation project grant report. Microbiologist, 11(3), 13.

Verran, J. (2013a). The Bad Bugs Bookclub: Science, literacy and engagement. Journal of Microbiology and Biology Education (JMBE), 14(1), 110-112.

Verran, J. (2013b). Mixed cultures: Microbiology, art and literature. In T. Bilham (Ed.), For the love of learning (pp. 21-28). Basingstoke, UK: Palgrave MacMillan.

Verran, J., \& Aldana Reyes, X. (2018). Emerging infectious literatures and the zombie condition. Emerging Infectious Diseases, 24(9), 1774-1778. http://e-space.mmu.ac.uk/id/eprint/620740.

Verran, J., Crossley, M., Carolan, K., Jacobs, N., \& Amos, M. (2013). Monsters, microbiology and mathematics: The epidemiology of a zombie apocalypse. Journal of Biological Education, 48(2), 98-104.

Verran, J., Haigh, C., Brooks, J., Butler, J., \& Redfern, J. (2018a, in press). Fitting the message to the location: Engaging adults with antimicrobial resistance in a World War 2 air raid shelter. Journal of Applied Microbiology. https://doi.org/10.1111/jam.13937. 
Verran, J., Redfern, J., Moravej, H., \& Adebola, Y. (2018b). Refreshing the public appetite for 'good bacteria': Menus made by microbes. Journal of Biological Education, 53, 34-46. https://doi.org/10.1080/00219266.2017.1 420678.

Wadman, M. (2017). The vaccine race: How scientists used human cells to combat killer viruses. London: Transworld Publishers.

Walters, M. (2017). The last hours. London: Allen \& Unwin.

Welsh, L. (2014). A lovely way to burn. London: John Murray.

White, G. (2008). Capturing the ethics education value of television medical drama. The American Journal of Bioethics, 8(12), 13-14.

Wilson, N. (2017). Broadbrows and book clubs. British Academy Review, 29, 44-46.

Wyndham, J. (1960). Trouble with lichen. London: Michael Joseph.

Yong, E. (2016). I contain multitudes: The microbes within us and a grander view of life. London: Bodley Head.

Yuan, R. T., \& Benson, S. A. (1995). Modern microbiology for nonmajors: teaching relevance. American Society for Microbiology (ASM) News, 61(1), $27-30$. 